\title{
PENGEMBANGAN ALAT PENGENDALI HAMA WERENG COKLAT TANPA PESTISIDA BERTENAGA KINCIR ANGIN YANG RAMAH LINGKUNGAN
}

\author{
Rindra Yusianto ${ }^{1}$, Usman Sudibyo ${ }^{2}$, Wisnu Adi Prasetyanto ${ }^{3}$

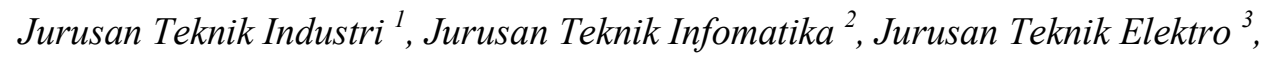 \\ Fakultas Teknik, Universitas Dian Nuswantoro, \\ Jl. Nakula I No. 5-11, Semarang, Jawa Tengah, 50131 \\ Email : rindra@staff.dinus.ac.id ${ }^{I}$
}

\begin{abstract}
Pests in rice crops, namely mice, stem borer and Wereng Coklat (Nilaparvata lugens Stal). Wereng coklat is classified as very dangerous for the rice crop. This pest is highly detrimental to the agricultural system in Indonesia, with attacks on a wide area in a short time. This pest control methods such as by controlling in farming, controlling the resistant varieties, physical controls and mechanical and biological control. That method is not effective, so a more practical way to control and quickly began to do that is chemically using pesticides. But the impact of pesticides is dangerous, especially due to the use unwisely. So that environmentally friendly technologies needed to control pests and ecosystem. Target of this research is to develop a prototype tool wereng coklat control without pesticides powered windmills that are environmentally friendly. Prototype are designed with two modes, namely automatic controlled with motion sensors and manual. Prototype was designed with a mechanical concept that is environmentally friendly, it is to reduce the effects caused by the use of chemical pesticides. The purpose of this research is to design wereng coklat pest control device with a motion sensor that consists of a mechanical vacuum and aluminum propeller. The mechanical vacuum linked to the pipe that tipped on light suction funnel. In the suction funnel installed motion sensors that serve to detect the presence/movement wereng coklat pests. The voltage source is derived from the modification of dry cell connected to a windmill which functioned as a generator. Dry cell store electricity converted from windmills. This study is experiment research with developed by tested prototype both pre and post test. The prototype developed by considering three factors: time of arrival (X1), time seedlings (X2) and the planting location (X3) against the number of catches (Y). This device does not use pesticides, but rather take advantage of the weakness of wereng coklat pest are very sensitive to light. Based on the test results we can conclude that the most influential variable to variable number of catches $(Y)$ is variable Planted Area (X3) with a coefficient of 0.372 . Then variable planting time (X2) with a coefficient of 0.355 and the smallest influence is variable arrival time (X1) with a coefficient of 0.140 .
\end{abstract}

Keywords : Wereng Coklat, Pest Controllers, Windmill.

\section{PENDAHULUAN}

Sampai saat ini hama masih menjadi kendala bagi petani. Hampir pada setiap musim terjadi ledakan hama pada pertanaman padi. Menurut Kusilwatiktanto (2011), hama utama tanaman padi antara lain tikus, penggerek batang dan wereng coklat. Wereng coklat (Nilaparvata lugens Stal) tergolong hama yang sangat berbahaya bagi tanaman padi (Syahrawati dkk, 2010). Hama ini sangat merugikan perpadian di Indonesia, dengan serangannya sampai puso pada areal yang luas dalam waktu yang relatif singkat (Kusilwatiktanto, 2011). Hama ini sangat sulit dikendalikan atau diberantas karena memiliki berbagai keunggulan yaitu mudah beradaptasi dan mampu membentuk biotipe baru dengan mentransfer virus kerdil yang daya rusaknya sangat hebat (Baehaki, 2009). Selain itu hama ini juga memiliki kemampuan mempertahankan generasi yang sangat baik (Marheni, 2004). Bahkan hama ini telah menjadi hama global (the very important global pest (Bhat, 2004). Tahun 2010 hama ini secara serentak juga menyerang tanaman padi di Vietnam, Thailand, China, India, Malaysia, Filipina, Pakistan, Korea dan Jepang. Menurut 
Baehaki dalam Yusianto, dkk (2015), periode tahun 1970-1980 luas serangan hama ini mencapai 2,5 juta ha. Kemudian periode 1980-1990 terjadi penurunan luas serangan, yaitu menjadi 50.000 ha, Namun dalam periode 1990-2000 kembali meningkat mencapai 200.000 ha.

Berbagai metode telah dilakukan petani untuk mengendalikan hama tersebut antara lain dengan pengendalian secara bercocok tanam, pengendalian dengan varietas tahan, pengendalian secara fisik dan mekanik dan pengendalian secara biologi (Sjakoer, 2010). Cara - cara pengendalian tersebut dianggap kurang efektif sehingga cara pengendalian hama yang lebih praktis dan cepat mulai dilakukan petani yaitu secara kimiawi memanfaatkan pestisida (Caraycaray, 2004). Ternyata dampak yang ditimbulkan dari metode ini sangat banyak (Frost, 2001). Bahaya pestisida semakin nyata dirasakan masyarakat, terlebih akibat penggunaan pestisida yang tidak bijaksana (Baehaki, 2009). Berdasarkan hal tersebut maka pemakaian alat pengendali hama wereng coklat tanpa pestisida sangat terbuka. Penggunaan alat pertanian yang ramah lingkungan ini akan menghasilkan bahan pangan yang aman bagi kesehatan, sekaligus mengurangi kerusakan ekosistem lingkungan.

Oleh karena itu diperlukan suatu teknologi ramah lingkungan yang dikembangkan untuk mengendalikan hama yang didasarkan kepada konsep Pengendalian Hama Terpadu (PHT) dengan mempertimbangkan ekosistem (Baehaki, 2009). PHT merupakan pengendalian hama yang memanfaatkan teknologi dengan pendekatan komprehensif berdasarkan ekologi serta mempertahankan kesehatan lingkungan dan menguntungkan bagi pihak lain (Hasibuan, 2008).

Salah satu indikator keberhasilan dalam rancang bangun alat pengendali hama wereng coklat adalah kemampuan menekan populasi wereng coklat sampai dengan $75 \%$ tanpa menggunakan pestisida (Baehaki, 2011). Secara umum, sistem kerja alat pengendali hama wereng coklat terdiri dari 4 (empat) komponen utama, yaitu (1) Corong; (2) Lampu Perangkap (Light trap); (3) Kantong Plastik; (4) Rangka Atap Seng. Prinsip kerja dari sistem alat pengendali hama adalah sebagai berikut : Lampu perangkap dipasang pada titik pusat corong yang berfungsi untuk menarik hama pada waktu malam hari. Di bagian bawah corong dipasang kantong plastik sebagai penampung hama. Corong dilindungi oleh rangka atas seng untuk menghindari tiupan angin dan hujan. Sampai saat ini, khalayak luas khususnya petani beranggapan bahwa sistem kerja ini merupakan sistem kerja yang paling efektif. Ada 3 (tiga) hal yang sebenarnya bisa lebih dioptimalkan lagi dari sistem ini, yaitu (1) corong yang memiliki kemampuan menyedot hama tertarik ke dalam; (2) penampung hama dengan pipa paralon dan katup penutup otomatis dengan modifikasi leher angsa; dan (3) motion sensor yang mampu menggerakkan baling-baling mekanik secara otomatis. Alat yang ada saat ini tidak mampu secara otomatis menyedot hama yang mendekati lampu, sehingga memungkinkan hama lepas dari perangkap. Selain itu unsur green technology juga bisa dilakukan dengan memodifikasi sumber tegangan.

\section{METODE PENELITIAN}

Penelitian ini merupakan penelitian eksperimen murni, yaitu penelitian yang dilakukan dengan membuat sebuah prototype yang diujicoba, pre dan post test. Penelitian dilakukan di dua lokasi yang memiliki karakteristik berbeda yaitu di kecamatan Genuk dan Gunungpati kota Semarang. Alat dipasang di empat titik berbeda selama 30 hari.

Berdasarkan hasil tangkapan maka akan dianalisis kapan puncak tangkapan populasi, waktu datangnya hama imigran, lokasi tanam dan jumlah tangkapan.

Pengembangan prototype alat pengendali hama wereng coklat tanpa pestisida bertenaga kincir angin dalam penelitian ini dapat dilihat pada road map berupa bagan alir sebagai berikut : 
Rancang Bangun Alat Pengendali Hama Wereng Coklat Mekanik Tanpa Pestisida. (Yusianto, R. dan Ngatindriatun. 2011)

\section{$\square$}

Alat Pengendali Hama Wereng Coklat dengan BalingBaling Mekanik dan Corong Penyedot. No. Permohonan Paten : P00201201022 tanggal 26 November 2012.

(Yusianto, R. dan Pindandita, S. 2012)

\section{$\square$}

Pengembangan Prototipe Alat Pengendali Hama Wereng Coklat Tanpa Pestisida yang Ramah Lingkungan dengan Baling-Baling Mekanik dan Corong Penyedot.

(Yusianto, dkk. 2013)

\section{$\square$}

Pengembangan Prototipe Alat Pengendali Hama Wereng Coklat Tanpa Pestisida yang Ramah Lingkungan dengan Baling-Baling Mekanik dan Corong Penyedot. Penelitian Lanjutan. (Yusianto, dkk. 2014)

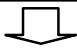

Alat Pengendali Hama Wereng Coklat Otomatis dengan Motion Sensor. No. Permohonan Paten : P00201508198 tanggal 04 Desember 2015. (Yusianto, dkk. 2015)

pengembangan prototipe alat pengendali hama wereng coklat tanpa pestisida bertenaga kincir angin yang ramah lingkungan (Yusianto, dkk. 2015)

Gambar 1. Bagan Alir Penelitian.

\section{HASIL DAN PEMBAHASAN}

\subsection{Inovasi Pengendali Hama}

Pada tahun 2011, peneliti telah melakukan penelitian berjudul Rancang Bangun Alat Pengendali Hama Wereng Coklat Mekanik Tanpa Pestisida. Pada penelitian tersebut luaran yang dihasilkan adalah alat pengendali hama wereng coklat dengan baling-baling mekanik dan corong penyedot. Alat masih bekerja secara manual karena pengoperasiannya harus menekan tombol power pada pangkal pipa yang terhubung dengan accu sebagai sumber tegangan. Dalam pengoperasiannya alat tersebut dibawa berpindah - pindah oleh petani. Indikator capaian penelitian tersebut adalah pada tiga kali uji coba alat, serangga yang dapat tertangkap yaitu 532 wereng coklat (Nilaparvata lugens Stal), 235 penggerek batang padi (Scirpophaga incertulas), 147 kepinding tanah (Scotinophara coarctata) dan 12 kumbang Coccinella. Kemudian pada tahun 2012, dilakukan pengembangan alat hasil penelitian penelitian tahun 2011. Luaran penelitian berupa penambahan motion sensor yang dilengkapi dengan LCD untuk menampilkan menu. Kecepatan putaran baling - baling dan kekuatan sedot corong dapat diatur sesuai kebutuhan. Uji coba dilakukan dengan indikator capaian adalah tiga pilihan kecepatan putar baling - baling mekanik, yaitu cepat, sedang dan lambat. Pada penelitian tahun 2013 dilakukan pengembangan prototype alat pengendali hama wereng coklat dengan baling - baling mekanik dan corong penyedot menggunakan sumber tegangan aki kering yang mampu di charge. Keunggulan penggunaan aki kering rechargeable ini adalah petani dapat menggunakan alat tanpa harus terhubung ke sumber tegangan $\mathrm{AC}$ yang sangat beresiko apabila digunakan di areal persawahan. Alat sudah dapat bekerja secara optimal. Dalam ujicoba pendahuluan serangga yang dapat tertangkap antara lain wereng coklat (Nilaparvata lugens Stal), penggerek batang padi (Scirpophaga incertulas), kepinding tanah (Scotinophara coarctata) dan kumbang Coccinella. Selanjutnya penelitian tahun 2014 yang merupakan pengembangan alat dari penelitian tahun 2013 yaitu pada bagian inti alat, baling - baling mekanik dan corong penyedot dirangkai dengan rangkaian yang terhubung dengan LCD. Alat dirancang dengan 2 mode, yaitu mode otomatis dan manual. Kedua mode ini menggunakan sumber tegangan dari aki kering rechargeable. Sedangkan pada penelitian ini dilakukan pengembangan berupa modifikasi aki kering yang terkoneksi ke kincir angin yang di fungsikan sebagai pembangkit energi. Aki kering akan menyimpan listrik yang dikonversi dari kincir angin yang dipasang di areal persawahan.

Pada penelitian ini dilakukan pengujian pengaruh waktu kedatangan (X1), waktu semai (X2) dan lokasi tanam (X3) terhadap jumlah tangkapan (Y). Pengujian alat dilakukan di dua lokasi yaitu di kecamatan Genuk dan Gunungpati kota Semarang. Alat dipasang di empat titik berbeda selama 30 
hari. Berdasarkan jumlah tangkapan dianalisis puncak tangkapan.

\subsection{State of The Art Penelitian}

Inovasi pengendali hama wereng coklat dalam penelitian ini memiliki perbedaan yang sangat mencolok dibandingkan dengan alat pengendali hama wereng coklat yang ada di pasaran atau yang dikenal oleh masyarakat luas. Yaitu alat ini sama sekali tidak menggunakan pestisida, namun lebih memanfaatkan kelemahan hama wereng coklat yang sangat sensitif terhadap cahaya lampu. Pengembangan prototype alat pengendali hama wereng coklat tanpa pestisida di ujicoba dengan menggunakan tenaga kincir angin yang ramah lingkungan, hal ini diharapkan dapat mengurangi efek kimiawi karena penggunaan pestisida yang kurang bijaksana.

Penangkapan dan pemusnahan hama dengan menggunakan alat ini diharapkan dapat lebih optimal dan mampu menekan populasi hama yang ada. Unsur green technology juga lebih ditekankan dalam pengembangan alat ini, yaitu dengan memodifikasi sumber tegangan.

\subsection{Spesifikasi Prototype}

Pada penelitian yang telah dilakukan sebelumnya, sumber tegangan berasal dari listrik AC, sedangkan dalam penelitian ini sumber tegangan dihasilkan dari kincir angin yang difungsikan sebagai pembangkit. Tenaga yang dihasilkan dari kincir angin disimpan pada aki kering. Tegangan yang berasal dari kincir angin ini digunakan untuk menggerakan mekanik vacuum berisi dinamo dan baling-baling kipas aluminium. Mekanik tersebut dihubungkan dengan pipa yang pada bagian ujungnya diberi corong penyedot. Pada corong penyedot dipasang lampu LED ultra light dan motion sensor yang berfungsi untuk mendeteksi gerakan hama wereng coklat. Apabila ada wereng yang mendekat pada lampu, maka motion sensor akan memberikan sinyal sehingga secara otomatis dinamo akan memutar mekanik baling-baling kipas dan menyedot udara dari luar masuk ke dalam kotak penampung.

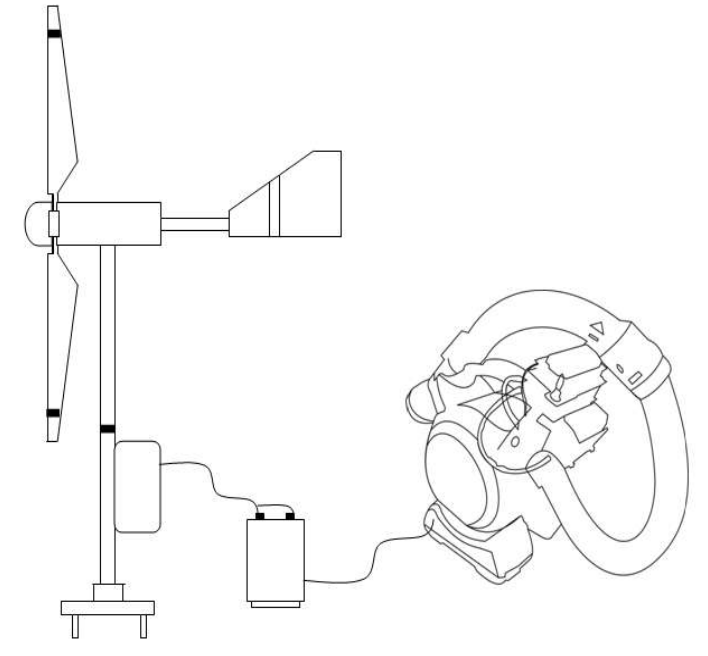

Gambar 2. Skema Prototype.

Pada gambar 2. Terlihat skema dan alur kerja prototype, sedangkan spesifikasi prototype secara teknis dapat dijelaskan sebagai berikut :

\section{(a) Letak Motion Sensor}

Letak motion sensor dipasang pada pangkal corong penyedot dan dikoneksikan dengan alat melalui pipa plastik.

(b) Jumlah Motion Sensor

Jumlah motion sensor minimal 1 (satu) buah dan dipasang pada bagian pangkal corong sejajar dengan lampu.

(c) Letak LCD

Letak Liquid Crystal Display (LCD) dipasang pada bagian depan atas dari alat ini. LCD dinyalakan dengan menekan tombol switch on off yang dipasang pada samping kanan LCD.

(d) Mode Pilihan Menu

Mode menu pilihan akan ditampilkan pada LCD dengan mode pilihan Auto dan Manual serta sebuah tombol reset.

(e) Letak Baterai rechargeable LCD

Letak baterai rechargeable LCD (dipasang pada bagian bawah LCD dan terkoneksi ke LCD melalui tombol switch on off .

(f) Jumlah Baling - baling

Jumlah sirip baling - baling minimal 2 (dua) buah dan dipasang pada pangkal kincir angin. 
Tabel 1 Hasil Analisis Regresi

\begin{tabular}{c|c|c|c|c}
\hline \multirow{2}{*}{ Variabel Bebas } & \multicolumn{2}{|c|}{ Koefisien } & \multirow{2}{*}{ t hitung } & \multirow{2}{*}{ p } \\
\cline { 2 - 3 } & B & Std. Error & & \\
\hline (Konstanta) & $-0,476$ & 1,459 & $-0,328$ & 0,746 \\
Waktu kedatangan (X1) & 0,140 & 0,069 & 2,076 & 0,048 \\
Waktu Semai (X2) & 0,355 & 0,157 & 2,278 & 0,031 \\
Lokasi Tanam (X3) & 0,372 & 0,180 & 2,083 & 0,047 \\
\hline
\end{tabular}

(g) Jenis Baling - baling

Jenis baling - baling adalah baling baling sumbu horizontal.

(h) Letak Controller

Letak controller dipasang pada batang penyangga kincir angin sejajar di atas pondasi.

(i) Letak Baterai Rechargeable

Letak baterai rechargeable dipasang pada bagian bawah alat pengendali.

Pengendali hama wereng coklat yang dikembangkan secara mekanik dengan baling-baling kipas aluminum dan corong penyedot berupa kerucut yang dikelilingi lampu pada bagian dalamnya dengan 4 buah motion sensor. Lampu tersebut dihubungkan dengan pipa paralon sepanjang minimal 30 $\mathrm{cm}$ dan maksimal $100 \mathrm{~cm}$ berbentuk leher angsa dengan katup penutup yang memiliki tebal plat $1 \mathrm{~mm}$ dibagian tengahnya. Motion sensor berfungsi untuk mendeteksi gerakan hama wereng coklat dan secara otomatis akan menyalakan dinamo 12 volt yang berfungsi untuk memutar mekanik baling-baling kipas dan menyedot udara dari luar masuk ke dalam kotak penampung hama berbentuk kotak persegi panjang yang dibagian belakangnya dipasang tabung vacuum dan accu sebagai sumber tegangan.

\subsection{Model Persamaan Regresi}

Model persamaan regresi yang baik adalah model yang memenuhi persyaratan asumsi klasik, diantaranya adalah data berdistribusi normal, model harus bebas dari multikolinieritas dan terbebas dari heteroskedastisitas. Dari hasil analisis sebelumnya, telah terbukti bahwa model persamaan yang diajukan dalam penelitian ini telah memenuhi persyaratan asumsi klasik, sehingga model persamaan dalam penelitian ini sudah dianggap baik. Berdasarkan hasil penelitian, diperoleh model persamaan regresi pada tabel 1 diatas.

Setelah dilakukan pengolahan data, maka didapatkan persamaan sebagai berikut :

$Y=-0.476+0,140 X_{1}+0,355 X_{2}+0,372 X_{3 .}$

Dimana :

Y : Jumlah Tangkapan.

$\mathrm{X}_{1}$ : Waktu Kedatangan.

$\mathrm{X}_{2}$ : Waktu Semai.

$\mathrm{X}_{3}$ : Lokasi Tanam.

Berdasarkan persamaan (1) di atas, dapat disimpulkan bahwa variabel yang paling berpengaruh terhadap variabel jumlah tangkapan (Y) adalah variabel Lokasi Tanam (X3) dengan koefisien 0,372. Kemudian variabel Waktu Semai (X2) dengan koefisien 0,355 dan yang paling kecil pengaruhnya adalah variabel waktu kedatangan (X1) dengan koefisien 0,140. Koefisien dari ke-3 variabel tersebut adalah bertanda positif, sehingga pengaruh ke-3 variabel tersebut berbanding lurus dengan variabel jumlah tangkapan.

\subsection{Prototype Alat}

Alat pertanian saat ini masih dominan menggunakan alat semprot pestisida dalam mengendalikan hama wereng coklat, padahal sistem pertanian organik yang digalakan pemerintah, mensyaratkan tidak diperbolehkan penggunaan bahan kimia baik pupuk maupun pestisida. Berdasarkan hal tersebut maka pemakaian alat pengendali hama wereng coklat tanpa pestisida sangat terbuka. 
Penggunaan alat pertanian yang ramah lingkungan ini akan menghasilkan bahan pangan yang aman bagi kesehatan, sekaligus mengurangi kerusakan ekosistem lingkungan. Salah satu indikator keberhasilan dalam rancang bangun alat pengendali hama wereng coklat adalah kemampuan menekan populasi wereng coklat sampai dengan $75 \%$ (Baehaki, 2010) tanpa menggunakan pestisida. Secara umum, sistem kerja alat pengendali hama wereng coklat terdiri dari 4 (empat) komponen utama, yaitu (1) Corong; (2) Lampu Perangkap (Light trap); (3) Kantong Plastik; (4) Rangka Atap Seng. Prinsip kerja dari sistem alat pengendali hama adalah sebagai berikut; Lampu perangkap dipasang pada titik pusat corong yang berfungsi untuk menarik hama pada waktu malam hari. Di bagian bawah corong dipasang kantong plastik sebagai penampung hama. Corong dilindungi rangka atas seng untuk menghindari tiupan angin dan hujan.

Sampai saat ini, khalayak luas khususnya petani beranggapan bahwa sistem kerja ini merupakan sistem kerja yang paling efektif. Ada 3 (tiga) hal yang sebenarnya bisa lebih dioptimalkan lagi dari sistem tersebut, yaitu (1) corong yang memiliki kemampuan menyedot hama; (2) penampung hama dengan pipa paralon dan katup penutup otomatis; dan (3) motion sensor yang mampu menggerakkan baling - baling mekanik penyedot secara otomatis. Alat yang ada saat ini tidak mampu secara otomatis menyedot hama yang mendekati lampu, sehingga memungkinkan hama lepas dari perangkap.

Perputaran baling - baling mekanik yang terdapat pada mesin vacuum cleaner yang dimodifikasi dapat kendalikan dari layar menu. Alat dirancang dengan 2 mode, yaitu mode otomatis dan manual. Kedua mode ini dapat diatur melalui menu dipslay. Baik mode otomatis maupun manual keduanya menggunakan sumber tegangan dari aki kering rechargeable yang dikoneksikan dengan baling - baling kincir angin.

\begin{abstract}
Adapun dokumentasi prototype hardware, software dan petunjuk penggunaan prototype alat ini adalah sebagai berikut :
\end{abstract}

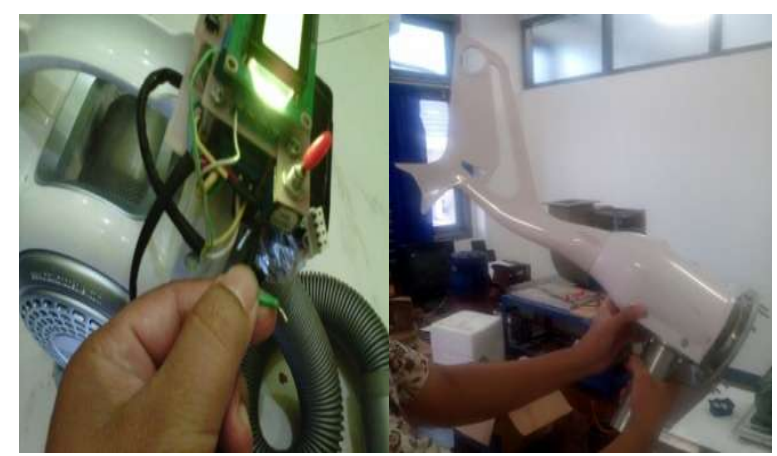

Gambar 3. Modul Menu dan Baling - Baling.

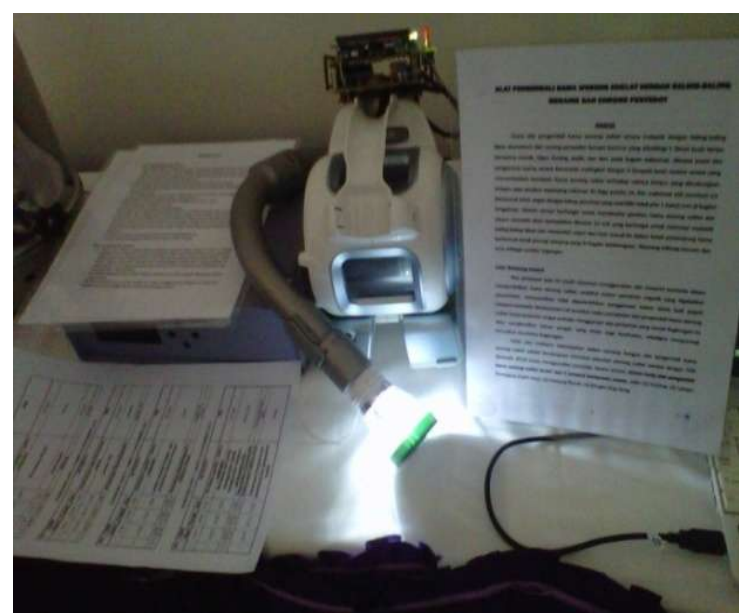

Gambar 4. Penjelasan Penggunaan.

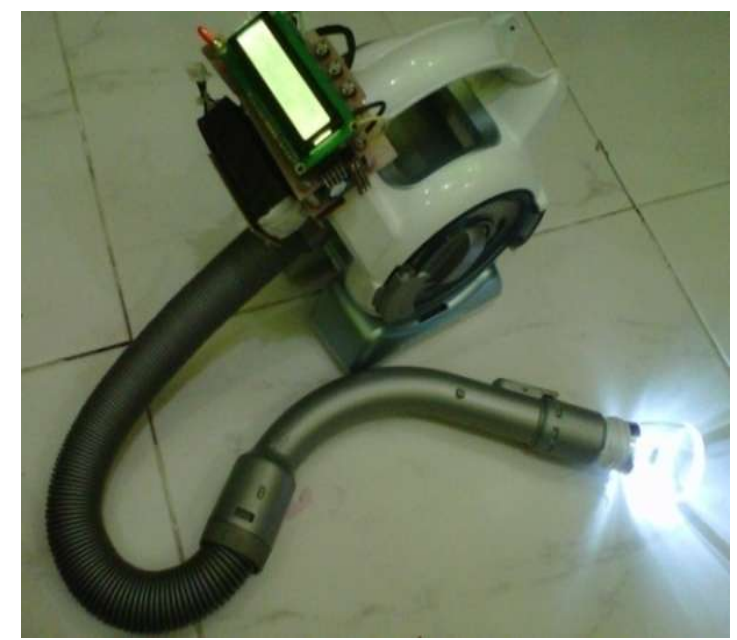

Gambar 5. Prototype Dalam Kondisi Siap di Ujicoba di Laboratorium. 


\section{KESIMPULAN}

Berdasarkan ujicoba, menunjukkan bahwa inovasi pengendali hama wereng coklat dalam penelitian ini memiliki perbedaan yang sangat mencolok dibandingkan dengan alat pengendali hama wereng coklat yang ada di pasaran atau yang dikenal oleh masyarakat luas.

Alat ini sama sekali tidak menggunakan pestisida, namun lebih memanfaatkan kelemahan hama wereng coklat yang sangat sensitif terhadap cahaya lampu.

Berdasarkan hasil regresi linier dapat disimpulkan bahwa variabel yang paling berpengaruh terhadap variabel jumlah tangkapan (Y) adalah variabel Lokasi Tanam (X3) dengan koefisien 0,372. Kemudian variabel Waktu Semai (X2) dengan koefisien 0,355 dan yang paling kecil pengaruhnya adalah variabel waktu kedatangan (X1) dengan koefisien 0,140. Koefisien dari ke-3 variabel tersebut adalah bertanda positif, sehingga pengaruh ke-3 variabel tersebut berbanding lurus dengan variabel jumlah tangkapan.

\section{Ucapan Terima Kasih}

Ucapan terima kasih kepada Direktorat Riset dan Pengabdian Masyarakat Kementerian Riset, Teknologi dan Pendidikan Tinggi yang telah memberikan dana hibah untuk penelitian ini.

\section{DAFTAR PUSTAKA}

Baehaki, S.U. Strategi Pengendalian Hama Terpadu tanaman Padi dalam Perspektif Praktek Pertanian yang Baik (Good Agricultural Practices). Jurnal Inovasi Pertanian 2(1). pp : 65-78, 2009.

Bhat, R. Improved Farmer Livelihood. ICM Edition, Bayer Crop Sci, 2004.

Caraycaray, M.D.B. More farmersuse innovative chemical - free methodsto control pest in rice. Phil. Rice Newsletter 16(4), 2003.
Frost, M. Quality Criteria and Standards. Berlinickestr, Berlin, Germany. p. 113121. Matthias.Frost@bvl. bund.de, 2001.

Hasibuan, M. Kajian Penerapan Pengendalian Hama Terpadu (pht) Pada Petani Padi di Kabupaten Tapanuli Selatan. Laporan Penelitian, 2008.

Kuswilwatiktanto, E. Strategi Pengendalian Hama Terpadu Tanaman Padi Dalam Perspektif Praktek Pertanian Yang Baik (Good Agricultural Practices). Laporan Penelitian, 2011.

Marheni. Kemampuan Beberapa Predator pada Pengendalian Wereng Batang Coklat (Nilaparvata lugens Stal.). Jurnal Natur Indonesia 6(2): pp. 84-86, 2004.

Sjakoer, NAA. Mortalitas Hama Wereng Punggung Putih Setelah dimangsa oleh Serangga Predator (Pengamatan Visualisasi di Green House). Jurnal ElHayah 1(2) : pp. 35-39, 2010.

Syahrawati, M. Busniah dan N. Nelly. Sosialisasi Teknik Konservasi Musuh Alami Wereng Coklat (Nilaparvata lugens) pada Petani Perempuan. Lembaga Pengabdian kepada Masyarakat Universitas Andalas. Padang, 2010.

Yusianto, R. dan Ngatindriatun. Rancang Bangun Alat Pengendali Hama Wereng Coklat Mekanik Tanpa Pestisida. Laporan Penelitian : Ipteks. UDINUS. Semarang, 2011.

Yusianto, R. dan Pindandita, S. 2012. Alat Pengendali Hama Wereng Coklat dengan Baling-Baling Mekanik dan Corong Penyedot. No. Permohonan Paten : P00201201022 tanggal 26 November 2012.

Yusianto, R. dan Wisnu Adi, P. 2015. Alat Pengendali Hama Wereng Coklat Otomatis dengan Motion Sensor. No. Permohonan Paten : P00201508198 tanggal 04 Desember 2015. 